\title{
ПРОБЛЕМИ СЕМАНТИЧКЕ ИНТЕРПРЕТАЦИЈЕ ДВОСТРУКО НЕГИРАНОГ НЕГЛАГОЛСКОГ ПРЕДИКАТА **
}

\begin{abstract}
У раду се на широком корпусу књижевноуметничког и публицистичког стила анализирају двоструко негирани неглаголски предикати са формалног и семантичког становишта. Нарочита пажња посвећена је проблемима семантичке еквиваленције двоструко негираних неглаголских предиката и њихових афирмативних еквивалената. Анализа је показала да степен семантичке еквиваленције зависи од типа антонима којем припада лексема употребљена у предикативу оваквих предиката.

Кључне речи: негација, двострука негација, множење негација, кавлитативни антоними, комплементарни антоними
\end{abstract}

\section{1. О двострукој негацији у српском језику}

Двострука негација у српском језику представља појаву употребе два негатора у склопу једне изреке. Она се може остваривати као сабирање негација, када та два употребљена негатора подржавају формално одрични статус реченице и као множење негација, које представља математичко-логички принцип који у језику доводи до тога да два негатора употребљена у склопу једне изреке дају афирмативну семантичку вредност читавом исказу.

Уколико применимо функционални критеријум, множење негација се може остваривати само у оквиру једног реченичног члана или се оно остварује између различитих реченичних чланова у монопредикатским реченицама. ${ }^{1}$ Под множењем негација у оквиру једног реченичног члана сматраћемо

\footnotetext{
${ }^{1}$ Множење негација се остварује и у појединим врстама или подврстама полипредикатских реченица. Више о томе у: Јелена Петковић, Синтакса и семантика двоструке негације у српском језику, необјављена докторска дисертација, Крагујевац, 2014.
} 
употребу два негатора ${ }^{2}$ уз исти реченични члан, које се у српском језику остварује једино: а) у генитивној предлошко-падежној конструкцији са предлогом без, и б) у оквиру предиката.

Будући да се синтаксичка реченична негација по правилу везује за предикат, у овом раду смо као основни критеријум за класификацију узели тип предикатске јединице у којем долази до множења негација. Ако пођемо од типа предикатске јединице, детаљном анализом корпуса долазимо до закључка да се множење негација остварује у свим типовима предиката: у оквиру простог глаголског предиката, у оквиру сложеног глаголског предиката, у оквиру неглаголског (именског/прилошког) предиката, у оквиру усложњеног предиката и у оквиру декомпонованог предиката, што илуструју следећи примери:

Теодору Ласкарису није недостајало храбрих дела $[\rightarrow$ Теодор Ласкарис је имао храбрих дела], међутим, нападача сврстаних у обруч беше далеко више и од највећег подухвата (Г. Петровић, 177).

Ma koliko se na prvi pogled činilo da je izvan osnovnog toka naše priče..., ne možemo da ne spomenemo $[\rightarrow$ морамо да споменемо] na ovom mestu one čudnovate freske koje ukrašavaju zidove kružnih stepeništa što vode na gornji sprat... (Д. Киш, 51).

Sve u svemu emisija nije nezanimljiva $[\rightarrow$ је занимьива], mada je, možda, malo preduga i praznjikava (А. Поповић, 159).

Министарство спољних послова Бугарске саопштило је да се никад нису водили незванични разговори $[\rightarrow$ увек су се водили званични разговори] са Сједињеним Америчким Државама о постављању делова ракетног штита на територији те земље (РТС, 19. 2. 2010).

Она није желела да буде несрећна $[\rightarrow$ желела је да буде срећна] (Курир, 25. 3. 2013).

Као резултат множења негација у оквиру двоструко негираног предиката, на формалном плану, добија се његова афирмативна вредност. Овакво превођење двоструко негираних предиката у њихове афирмативне еквиваленте, када су задовољени сви нужни и сви довољни услови, није се показало проблематичним (будући да смо успели за све ексцерпиране примере из корпуса да реконструишемо њихове формалне афирмативне еквиваленте) и оно се одвија по логичком принципу двоструке негације, по коме негација негације даје афирмацију. Оно што се показало проблематичним јесте питање семантичке еквиваленције двоструко негираних предиката и њихових формалних афирмативних еквивалената.

Ако погледамо са формалног аспекта, задржавајући се само на двоструко негираном неглаголском предикату, множење негација се остварује између (1) негације коју садржи негирана копула и (2) негације коју садржи лексема употребљена у функцији предикатива или негације коју садржи префикс уз придев у саставу конгруентне именичке синтагме у предикативу. Резултат оваквог множења негација јесте предикат са афирмативном копулом и антонимом негиране лексеме употребљене у функцији предикатива. Будући да је негација коју садржи негирана копула у оквиру неглаголског предиката неспорна, проблем семантичке еквиваленције очигледно лежи у неглаголском

\footnotetext{
${ }^{2}$ Под термином негатор подразумеваћемо „сваки језички елемент који служи за одрицање. У оквиру просте реченице негатори су увијек партикуле не и ни, сви одрични префикси, као и одрични приједлози без и против" (Ковачевић 2004: 169).
} 
делу оваквог предиката, и зависи, као што ћемо то надаље показати, од типа лексеме која се налази у функцији именског / прилошког предикатива.

Из напред наведеног јасно је да се приликом множења негација у оквиру двоструко негираног неглаголског предиката проблеми реченичне негације укрштају са проблемима лексичке негације. ${ }^{3}$ Не улазећи дубље у питања лексичке негације, антонимије и саме поделе антонима у овом раду, запазићемо да је основни проблем који се јавља у вези са двоструко негираним неглаголским предикатима, код којих је у предикативу негативно префигирана лексема, тај што негацијом негативно префигиране лексеме не добијамо увек прави антоним, већ врло често и неправи, „који је семантички асиметричан с лексемом од које потиче"4 (Драгићевић 2007: 273). У том смислу, за наше је разматрање од највеће важности понашање квалитативних (степенованих, градабилних) антонима и комплементарних (нестепенованих, неградабилних) антонима када се нађу у предикативу двоструко негираног неглаголског предиката.

\section{2. Множење негација у оквиру неглаголског предиката у којем је у предикативу квалитативни антоним са префиксом не-}

При разматрању антонима, без обзира на аутора или метод којим се антоними проучавају, увек се полази од чињенице да су антоними речи које у суштини имају сва својства заједничка сем једног својства које их и доводи у супротност.

Квалитативни, степеновани антоними заснивају се на логичком односу контрарности (млад-стар, врућ-хладан, паметан-глуп, велик-мали, глаcaн-тих, добар-лош). Степеноване опозиције су такве опозиције „чији се чланови карактеришу различитим степеном или градацијом једног истог својства" (Л. А. Новиков: цитирано према Драгићевић 1996: 29). Квалитативном антонимијом Љ. Шарић сматра основни, најјаснији начин изражавања супротности, то су „,antonimi koji izražavaju stupnjevitu kakvoćnu suprotnost (topao - hladan, mlad-star, mladost-starost) i realiziraju kontrarnu suprotnost" (Шарић 2007: 115).

Већ је К. Цимер (Цимер 1966) тврдио да се не може говорити о негацији свих придева уопштено, већ да постоје разлике које зависе од тога ком логичком типу појмова дати придев припада. Негирање придева који припадају контрарним антонимима не даје у резултату сам тај придев, што он илуструје примером not unlikely (није невероватно), који по његовим речима

\footnotetext{
${ }^{3}$ Под лексичком негацијом подразумевамо негацију именичких, придевских, прилошких и заменичких речи, која се остварује домаћим префиксима не- и без- (код именица, придева и прилога) и префиксом ни- (код заменица и заменичких прилога), и префиксима страног порекла $a-, \partial и c-, u-$ и $и н-$.

${ }^{4}$ У литератури се обично наводи пример лексеме леп, која са префиксом не- не мора да значи ружан, већ има шири семантички опсег, може значити није ни леп ни ружан, неутралан (или амбивалентан).
} 
може значити likely (вероватно), али се може налазити и у великој области индиферентности у којој нити је likely (вероватно) нити је unlikely (невероватно). Исто објашњење К. Цимер нуди и за придев happy (срећан), док на супротном полу, по његовом мишљењу, стоје придеви типа inconceivable (неcхватљив) или impossible (немогућ), чијим негирањем једино можемо добити conceivable (разумлив, схватљив) и possible (могућ, вероватан), и за које не постоји та тзв. зона индиферентности у којој би се могли наћи афирмативни пандани двоструко негираних придева. К. Цимер је, подстакнут Јесперсеновим опажањем да већина придева са префиксом иn- има склоност да умањује вредност неког смисла, ${ }^{5}$ понудио правило у коме каже да се негативни префикси не комбинују са придевима који имају негативну вредност на вредносној скали, као што су нпр. придеви добар-лош, пожељан-непожељан. ${ }^{6} \mathrm{~K}$. Цимер признаје и да задатак позитивне и негативне вредности мора некако да буде остављен интуицији за процену.

Неки истраживачи о двоструко негираним неглаголским предикатима са степенованим контрарним антонимима говоре и као о семантички паразитским конструкцијама, иако оне нису потпуно семантички еквивалентне афирмативним придевима, при чему они сматрају да се израз типа not unhappy person (не несрећна особа) увек интерпретира као незнатно до умерено срећна особа. Овај паразитски однос посебно је истакнут у случајевима у којима се негативно префигираним придевима додељује читање које није могуће изван двоструко негираних придевских форми (уп. Хорн 1989: 299).

Из напред наведеног је јасно да у двоструко негираним неглаголским предикатима код којих је у функцији предикатива нека лексема префигирана не- префиксом, која припада подтипу квалитативних, степенованих антонима, проблем настаје у обиму семантичке еквиваленције таквих двоструко негираних исказа и њихових формалних афирмативних еквивалената, због чињенице да негацијом квалитативног антонима не добијамо нужно његов афирмативни еквивалент, већ у великом броју примера добијамо неки од прелазних ступњева између два пола.

Наши су примери из корпуса показали да се негацијом квалитативног антонима углавном добија појам који се налази негде на средини скале између супротних вредности, или пак, ближе левом или десном полу, што не може бити прецизирано без увида у шири контекст употребљеног израза и посебне прагматичке разлоге употребе оваквих конструкција.

Sve u svemu emisija nije nezanimljiva $[\sim$ jе занимљива], mada je, možda, malo preduga i praznjikava (А. Поповић, 159).

\footnotetext{
${ }^{5}$ Уп.: ,...that most adj with un- have a depreciatory sense" (Јесперсен 1942, цитирано према Цимер 1962: 134).

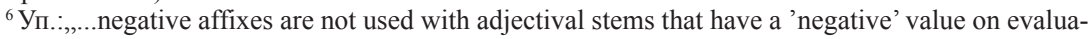
tive scales such as good-bad, desirable-undesirable” (Цимер 1966: 135).

${ }^{7}$ „Antonimni se parovi iz ove skupine shvaćaju kao postupan prijelaz uzrokovan postupnim negacijama od proturječnih i nedostatno sadržajno definiranih pojmova ka krajnjim, suprotnim: vreo; ne-vreo, topao; ne-topao, prohladan; ne-prohladan, hladan" (Шарић 2007: 107).
} 
Kako da raskid ne bude neprijatan [ буде пријатан] i da se ipak, bez obzira na sve, zadrži neki nivo dostojanstva posle njega, objašnjava pevač Saša Kovačević (Cosmopolitan, jun 2012, 39).

Није неуобичајена $[\sim$ Уобичајена је] ни $[\rightarrow$ и] допуна којом се експлицира креатор перцепираног садржаја или сам садржај, који се прво физички - чулом слуха, преноси до субјекта, а затим препушта когницији (Арсенијевић 2012: 94).

Radio nije nezanimljiv [ је занимљив] medij (Ало, 15. 4. 2012)

Moram reći da nije nejasno[ je jacho] ko upravlja Vučićevim kabinetom (PTC, 15. 10. 2016).

Izgledalo je da nije nesrećan [ je cрећан] ${ }^{8}$ (Курир, 23. 9. 2016).

Негацијом негације квалитативног антонима, како смо истакли, добијамо релативни синоним позитивном антонимском парњаку и вредност литотизације 9 овог типа антонима управо и лежи у чињеници да се на овај начин добија много експресивнији антонимски парњак и да постоји могућност избора између афирмативне лексеме и потврдног израза који је добијен двоструком негацијом. Експресивна вредност литотизације оваквих антонима, који су засновани на логичком односу контрарности, почива на чињеници да негацијом контрарног антонима не добијамо потпуно семантички еквивалентан афирмативни парњак, већ негирани антоним покрива и пол свог опозитума и вредност неког средњег појма између ова два пола. А будући да највећи број квалитативних антонима познаје читаву скалу прелазних вредности која се може успоставити између два супротна пола, литотизација овог типа антонима преводи, заправо, антонимију у градацију (више о томе в. Ковачевић 2000). Но, из контекста је, у највећем броју случајева, могуће недвосмислено закључити покрива ли литотизирани антоним средњу вредност или је синониман са супротним полом. Због чињенице да српски језик показује „одсуство склоности ка прављењу негативних синтагми, ка стављању речце за негацију пред различите врсте речи у њиховим различитим облицима" (Грицкат 1961-62: 124), те у том смислу граматичка негација има предност над унутарлексичком, у великом броју примера из корпуса литотизирани антоним је покривао вредност средњег појма између два супротна пола, што ћемо илустровати следећим примерима:

$\mathrm{Na}$ više od trideset načina, od kojih nijedan nije nepristojan $[\rightarrow$ од којих је сваки подношиьив / од којих сваки није ни пристојан ни непристојан], орisivao je svoje obavljanje male nužde, koje su sve do jedne evidentirane (Политика, 5. 11. 2007, ЕК).

Iako je mlađi od mene, debeljuškast, rumenkast u licu, crnih, živahnih očiju, malkice uraslih, nije nezanimljiv [ $\rightarrow$ нити је занимљив нити је незанимљив] (Политика, 28. 11. 2000, ЕK), и др.

Са прагматичког аспекта посматрано, множење негација доводи до питања који су то разлози који у комуникативном чину условљавају да се говор-

\footnotetext{
8 Значење овог примера није потпуно идентично као значење истог примера без негације, јер постоји извесна нејасноћа која се односи на субјектову позицију на 'скали среће', како тврди Ван дер Вуден (Ван дер Вуден 1995: 2), која може бити негде између умерено срећан и потпуно екстатичан.

${ }^{9}$,Литота се најчешће остварује као употреба граматички негиране умјесто лексички афирмативне јединице (уп. нпр. не вољети = мрзјети, није добро = лоше је и сл.)" (Ковачевић 2000: 117).
} 
ник определи за двоструко негирани исказ уместо, формално и семантички, знатно једноставнијег позитивног исказа. Овакво опредељење, у први мах закључујемо, у супротности је са принципом језичке економије по коме би говорници требало да теже да у својим исказима користе језичка средства која изискују што мањи утрошак вербалне и менталне енергије, што води у правцу употребе афирмативних исказа насупрот њиховим двоструко негираним варијантама. Међутим, свакодневна комуникација и писани језик демантују овакву претпоставку, будући да се двоструко негирани искази срећу у свим функционалним стиловима и њиховим жанровима.

\section{3. Множење негација у оквиру неглаголског предиката у којем је у предикативу комплементарни антоним са префиксом не-}

У основи нестепенованих антонима леже логички комплементарни појмови и они се не могу односити на један исти денотат (унутрашьи - спољашьи, ожењен - неожењен, крив - прав, жив - мртав) и „негација једног члана пара нестепенованих антонима подразумева афирмацију другог члана пара (онај који није мртав, жив је и обрнуто, оно што није истинито, мора бити лажно)" (Драгићевић 1996: 30). У овом смислу одрицањем једног члана антонимског пара нестепенованих антонима, не добијамо само негирану лексему, већ и нову антонимичну лексичку вредност. ${ }^{10}$

Р. Драгићевић (уп. Драгићевић 2007) модификује неке од ових разлика, говорећи да није сасвим тачно да се нестепеновани антоними не могу компарирати, будући да, на пример, један човек може бити вештији од другог, може бити невернији и сл. Аутор такође, скреће пажњу и на то да се негирањем, тј. додавањем речце не- испред придева или именица, у неким случајевима уопште не добијају лексеме које стоје у антонимском односу, већ се могу добити лексеме које имају сасвим различиту архисему (уп. поверљив: неповерљив, према РСЈ 1. заснован на поверењу, отворен, искрен. 2. који одаје поверење, који улива поверење : који нема поверењ у у некога, у нешто, сумњичав; који изражава неповерење).

У двоструко негираним исказима у којима се остварује множење негација у предикату, уколико је у предикативу негативно префигирана лексема која припада класи комплементарних, нестепенованих антонима, будући да таква негативно префигирана лексема стоји у логичком односу комплементарности према својој позитивној лексеми, који подразумева да такве две лексеме исцрпљују целокупан опсег родног појма, те да негација једног члана таквог антонимског пара подразумева афирмацију другог члана пара, се-

\footnotetext{
${ }^{10}$ Као што смо већ показали, за степеноване антониме овакав однос не важи апсолутно, јер се негирањем контрарних појмова не може добити антоним, ,jер та негација често резултира појмом неодређеног значења или мноштвом појмова” (Драгићевић 1996: 33). Аутор то објашњава примером лексеме нелеп која не може бити антоним лексеме леп будући да може значити или који није ни леп ни ружан, или који је мање леп или значи који је ружан.
} 
мантичка еквиваленција двоструко негираног исказа и његовог афирмативног еквивалента је потпуна.

Разлози који опредељују говорника да употреби двоструко негирани исказ уместо потврдног нису структурно-синтаксичке природе, већ су, према нашим закључцима, у највећој мери мотивисани контекстуалним, ванјезичким и прагматичким факторима. У основи избора између два формално различита начина изражавања, када је овај тип множења негација у питању, будући да се ради само о формалној, али не и о семантичкој разлици, лежи „избор између двију могућности - лексичке и синтаксичке антонимности - a пошто је сваки избор стилистички условљен, управо у томе и треба тражити основ стилске вриједности овакве литоте” (Ковачевић 2000: 123). М. Ковачевић овакве примере литоте једино и сматра правом литотизацијом и каже „о правој литотизацији код контрадикторних антонима можемо говорити само онда кад се литотизује негативни антоним" ${ }^{\prime 11}$ (Ковачевић 2000: 124). Стилематичност оваквих литотизираних конструкција везује се за могућност избора између синонима који имају потпуно исто денотативно значење, али је литотизирани антоним увек обогаћен конотативном вредношћу.

Generalni menadžer košarkaške Jadranske lige Roman Lisac rekao je novinarima da nije nemoguće [ $\rightarrow$ je могyћe] da Beograd bude domaćin završnog turnira, a ocenio je i da se bliži vreme kada će navijači moći da putuju na gostovanja u region. (http://www.sportske.net/vest/kosarka/kako-u-hrvatskoj-i-sloveniji-gledaju-na-srpsku-dominaciju-116005.html, 18. 2. 2013)

Završni turnir u Laktašima bi trebalo da bude održan od 25. do 27. aprila ali ne bi bilo nezamislivo [ $\rightarrow$ било би замисливо / могло би да се замисли] da Igokea zaista otkaže organizaciju jer taj klub ne može da bude veći gubitnik no što je sada, pa i eventualna kazna ABA lige ne bi nanela veliku štetu pobedniku ligaškog dela sezone. (http://www.sportske.net/vest/kosarka/trener-igokee-zahteva-da-f4-bude-otkazan-121313.html, 26. 3. 2013)

...ни паралелне комбинације нису неочекиване [ $\rightarrow$ очекиване су] (Наслеђе 21, 2012, 54).

Л. Хорн (уп. Хорн 1989) сматра да говорници употребљавају двоструко негиране изразе у свим оним случајевима када желе да заобиђу да на једноставан начин о нечему реферишу речима позитивног значења. Његово мишљење је да двоструко негирани искази имају знатно јаче значење од једноставних позитивних исказа, и како он наводи не-неX ће у сваком контексту имати јаче значење од самог $X$, тј. неће бити незнатно до умерено $X$, него екстремно Х(Хорн 1989: 304).

Међутим, нису сви лингвисти оваквог мишљења, Х. Марцханд сматра да Јесперсенова тврдња ${ }^{12}$ о заобилазном путу који се постиже двоструком негацијом није у основи природног лингвистичког инстинкта који не прави тако префињен заобилазни пут да од негације негације добије афирмацију.

\footnotetext{
${ }^{11}$ Конкурентност синтаксички негираног а лексички афирмативног антонимског парањака и синтаксички афирмативног а лексички негативног антонима, М. Ковачевић само условно подводи под литоту, будући да „она [литота] то и није пошто не потврђује негирајући супротно - у позицији једног антонима само конкуришу двије негиране форме: синтаксичка и лексичка, синтаксичка која подразумијева негацију афирмације, и лексичка која у исказу подразумијева афирмацију негације” (Ковачевић 2000: 124).

12 У својим делима Јесперсен је о двострукој негацији говорио као о заобилазном путу (detour) који двоструко негирани искази прелазе од формално одричног статуса до афирмативне семантичке вредности.
} 
За њега су примери типа енглеског not uncommon, not unhappy једноставно колокације које стоје изван онога што је дозвољено природним лингвистичким инстинктом.

Терминима комуникативне прагматике речено, афирмативне и негативне тврдње могу бити два различита говорна акта, док се, тврди Р. Ђиора (уп. Ђиора 2006) употребом одричне реченице може постићи исто што и употребом потврдне. С друге стране, има аутора који тврде да се одричном реченицом преноси мања количина информације него што би се то урадило потврдном реченицом, те је у том смислу она мање информативна и самим тим биће избегнута увек када је могуће уместо ње употребити потврдну реченицу.

\section{4. Закључак}

Неглаголски предикати у којима се негација јавља и у копули и у предикативу подлежу језичком принципу множења негација, који стоји у тесној вези са логичким принципом двоструке негације, по којем двострука негација неког исказа јесте сам тај исказ. У резултату двоструке негације у неглаголском предикату добија се формално афирмативна вредност таквог предиката, док семантичка еквиваленција оваквих двоструко негираних предиката и њихових афирмативних еквивалената зависи од типа лексеме која је употребљена у функцији предикатива, тј. од типа антонима којем дата лексема припада.У двоструко негираним неглаголским предикатима, код којих је у функцији предикатива нека лексема префигирана не- префиксом која припада подтипу квалитативних антонима, семантичка еквиваленција таквих двоструко негираних исказа и њихових формалних афирмативних еквивалената није апсолутна због чињенице да негацијом квалитативног антонима не добијамо нужно његов афирмативни еквивалент, већ најчешће добијамо неки од прелазних ступњева између два пола. Уколико се у двоструко негираном неглаголском предикату у предикативу нађе негативно префигирана лексема која припада класи комплементарних антонима, будући да таква негативно префигирана лексема стоји у логичком односу комплементарности према својој позитивној лексеми, који подразумева да такве две лексеме исцрпљују целокупан опсег родног појма, те да негација једног члана таквог антонимског пара подразумева афирмацију другог члана пара, семантичка еквиваленција двоструко негираног исказа и његовог афирмативног еквивалента је потпуна. 


\section{ИЗВОРИ}

Д. Албахари - David Albahari, Mamac, Beograd: Stubovi kulture, 1997.

И. Андрић - Иво Андрић, Травничка хроника, Сарајево: Свјетлост, 1951.

И. Андрић ${ }^{1}$ - Иво Андрић, На Дрини ћуприја, Сабрана дела Иве Андрића, књига прва, Београд: Просвета - Загреб: Младост - Сарајево: Свјетлост - Љубљана: Државна заложба Словеније - Скопје: Мисла - Титоград: Побједа, 1981.

Г. Петровић - Горан Петровић, Опсада иркве Св. Сnaca, Београд: Политика, Народна књига, 2004.

Д. Киш - Danilo Kiš, Rani jadi, Zagreb: Globus, Beograd: Prosveta, 1983.

A. Поповић - Aleksandar Popović, Mrešćenje šarana, Beograd: BIGZ, 1986.

Kurir, Београд (доступно на http://kurir.rs/)

Cosmopolitan, Београд

Политика, Београд (доступно на http://www.politika.rs/)

Blic, Београд (доступно на http://www.blic.rs/)

\section{ЛИТЕРАТУРА}

Бондаренко 1983: В. Н. Бондаренко, Отрицание как логико-грамматическая категория, Москва: Наука.

Бошков 1981: Дана Бошков, „Придевска негација префиксима (не-, $a$-, $\partial u c-$, без-)", Наш језик, XXV/1-2, 63-68.

Ван дер Вуден 1995: Ton Van der Wouden, „Litotes and downward monotonicity”, Negation: A Topic in Focus (ed. Heinrich Wansing), Berlin, 1-19 (dostupno na http://www.tonvanderwouden.nl/index_files/papers/leipzig.pdf).

Грицкат 1961-1962: И. Грицкат, „О неким проблемима негације у српскохрватском језику", Јужнословенски филолог, XXV, 115-136.

Грицкат 1961-1962': И. Грицкат, „О антонимији”, Зборник за филологију и лингвистику, IV-V, 87-90.

Дабић 1984: Богдан Дабић, „Привативни префикси не- и без- у словенским језицима", Книжевни језик, XIII/4, Сарајево, 191-198.

Драгићевић 1996: Рајна Драгићевић, „О правим именичким и придевским антонимима", Јужнословенски филолог, LII, 25-39.

Драгићевић 2007: Рајна Драгићевић, Лексикологија српског језика, Београд: Завод за уџбенике.

Ђиора 2006: Rachel Giora, „Anything negatives can do affirmatives can do just as well, except for some metaphors", Journal of Pragmatics, 38, 981-1014 (dostupno na http://www.tau.ac.il/ giorar/files/Giora2006_anything_negatives_can_do.pdf).

Ковачевић 2000: М. Ковачевић, Стилистика и граматика стилских фигура, Крагујевац: Кантакузин. 
Ковачевић 2002: М. Ковачевић, Синтаксичка негација у српскоме језику, Ниш: Издавачка јединица Универзитета у Нишу.

Ковачевић 2004: М. Ковачевић, Огледи о синтаксичкој негащији, Српско Сарајево: Завод за уџбенике и наставна средства.

Петковић 2009: J. Петковић, „Синтаксичка негација у светлу математичке и логичке негације”, Савремена проучавања језика и књижевности I/1 (ур. М. Ковачевић и др.), Крагујевац, 75-83.

Петковић 2011: Ј. Петковић, „О једном проблему негације у језику штампе”, $\mathrm{Ha}$ ука и политика, (ур. М. Ковачевић), Пале: Филозофски факултет, 143-152.

Ристић 1961-1962: О. Ристић, „Функција префикса не- у неким именичким и придевским композитима", Јужнословенски филолог, XXV, 385-393.

Хорн 1989: L. Horn, A natural history of negation, Chicago: University of Chicago Press,(доступно на http://emilkirkegaard.dk/en/wp-content/uploads/Anatural-history-of-negation-Laurence-R.-Horn.pdf).

Хорн 2010: L. Horn, Multiple negation in English and other languages, The Expression of Negation (ed. L. R. Horn), Berlin - New York: Walter de Gruyter, 111-149.

Цимер 1966: K. Zimmer, „Affixal Negation in English and Other Languages”, Language,42/1,134-142,доступнонаһttp://www.jstor.org/discover/10.2307/ 411609 ? uid $=3738928 \&$ uid $=2129 \&$ uid $=2134 \&$ uid $=2478453753 \& u$ $\mathrm{id}=2 \&$ uid $=2478453743 \&$ uid $=70 \&$ uid $=3 \&$ uid $=60 \&$ sid $=21104411588823$.

Шарић 1992: Lj. Šarić, „Antonimija: neke značenjske i tvorbene odrednice”, Rasprave ZHJ, 18, Zagreb, 177-191.

Шарић 2007: Lj, Šarić, Antonimija u hrvatskome jeziku: semantički, tvorbeni $i$ sintaktički opis, Zagreb: Hrvatska sveučilišna naklada.

Jelena Petković

PROBLEMS OF SEMANTIC INTERPRETATION OF DOUBLE NEGATED NON-VERBAL PREDICATE

Summary

The paper analyses the examples of the use of a double negated non-verbal predicates, from the functional and semantic perspective. Using two negators in this type of predicate results in formally negative predicate, which on the semantic level has an affirmative value. In this paper, special attention is devoted to examining the degree of semantic equivalence of double negated non-verbal predicates and their affirmative equivalents. The analysis showed that the degree of equivalence depends on the type of lexemes used with predicative function. If qualitative antonym with prefix ne- is found in the predicative, double negated statement is not completely semantically equivalent to its affirmative pair, and if complementary antonym with prefix $n e$ - is found in the predicative, on the other hand, semantic equivalence of double negated statement and its affirmative equivalent is complete.

Key words: negation, double negation, multiplication of negation, qualitative antonym, complementary antonym. 